\title{
MOG antibodies in combined central and peripheral demyelination syndromes
}

Rocio Vazquez Do Campo, MD, Alana Stephens, MD, I. Vanessa Marin Collazo, MD, and Devon I. Rubin, MD

Neurol Neuroimmunol Neuroinflamm 2018;5:e503. doi:10.1212/NXI.0000000000000503
Correspondence

Dr. Vazquez Do Campo

vazquezdocampo.rocio@mayo.edu

Antibodies against myelin oligodendrocyte glycoprotein (MOG) have been identified in CNS inflammatory demyelinating disorders (IDDs) including neuromyelitis optica spectrum disorders (NMOSDs) without aquaporin-4 (AQP-4) antibodies. As in NMOSD, spinal cord and optic nerves are 2 of the most frequently involved CNS sites in combined central and peripheral demyelination (CCPD) syndromes. ${ }^{1-3}$ Spinal cord lesions of variable length and abnormal visual evoked potentials with and without clinical optic neuritis have been commonly described in CCPD series and single reports, but AQP-4 antibodies were detected in a minority of patients. ${ }^{1-4}$ MOG antibodies have not been reported in CCPD cases, and their role in CCPD is largely unknown. The clinical relevance of previously suggested antigens, such as neurofascin-155 (NF-155), expressed both in peripheral and central myelin, remains controversial. We present a CCPD case with elevated serum MOG-IgG1 antibodies and suggest their potential role in CCPD syndromes.

\section{Case report}

An 18-year-old man developed numbness and weakness in the left upper extremity and bilateral lower extremities, loss of bladder and bowel control, and erectile dysfunction over a 3-week period. There was no preceding infection or vaccination, and he denied visual symptoms. On examination, he had features of both CNS and peripheral nervous system (PNS) involvement, including right facial and trigeminal nerve dysfunction, mild left upper motor neuron pattern of weakness, with superimposed left wrist and foot drop, length-dependent sensory deficits in the lower extremities, reduced patellar reflexes, absent Achilles reflexes, and left arm hyperreflexia. A T8 sensory level and equivocal plantar responses were noted. MRI studies revealed multiple contrast-enhancing T2/fluid-attenuated inversion recovery hyperintense lesions in supratentorial and infratentorial brain structures, cervical spine (involving $\geq 3$ vertebral segments), thoracic spine, and conus medullaris (figure, A, C, E, G) and diffuse thickening and enhancement of the lumbosacral nerve roots. Nerve conduction studies showed a patchy, predominantly demyelinating neuropathy with absent left tibial $\mathrm{F}$ waves and abnormal temporal dispersion or conduction block in the left tibial, median, and radial motor nerves, resembling multifocal acquired demyelinating sensory and motor neuropathy. CSF revealed $20 \mathrm{cells} / \mathrm{mm},{ }^{3}$ protein of $80 \mathrm{mg} / \mathrm{dL}$, and 6 CSF-restricted oligoclonal bands. A sural nerve biopsy confirmed the presence of an inflammatory demyelinating neuropathy (figure, I-K). The patient's serum was negative for antibodies against GM1, GD 1a, GD1b, GQ1b, contactin-1, sulfatides, NF (NF155, NF-140), and myelin-associated glycoprotein. AQP-4 antibodies and paraneoplastic antibody panel (including CRMP-5) were negative in serum and CSF. Infectious, toxic-metabolic, granulomatous and infiltrative processes, hereditary neuropathies (including CMT1A, CMT1B, CMT1X, and hereditary neuropathy with liability to pressure palsies), and inherited leukodystrophies (adrenomyeloneuropathy, metachromatic leukodystrophy, and Krabbe disease) were excluded by pertinent additional testing. Elevated serum MOG-IgG1 antibodies were detected using a clinically validated live cell-based assay. ${ }^{5}$ A diagnosis of MOG antibodyrelated demyelinating disease was made. Intravenous corticosteroids resulted in clinical 


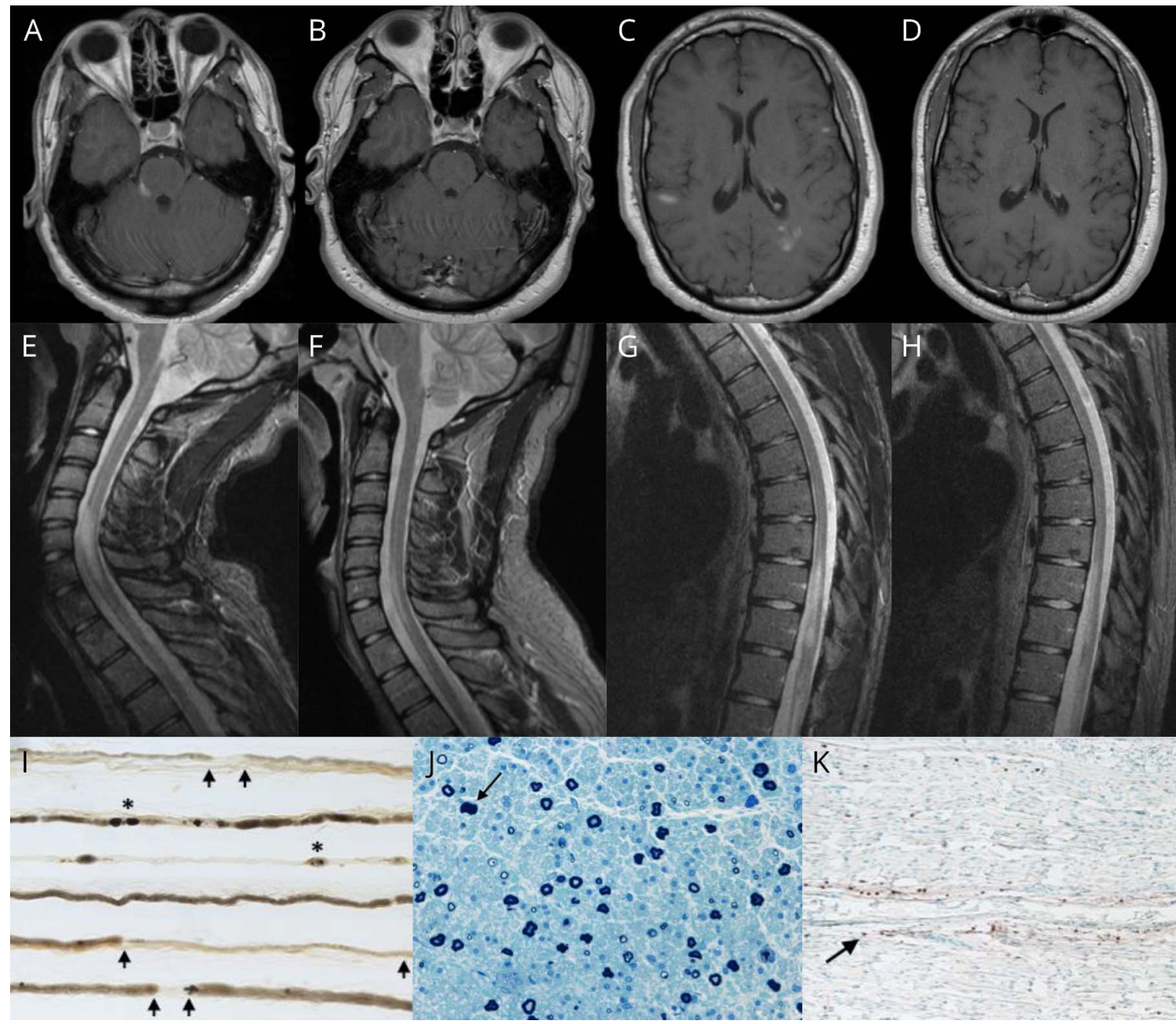

(A) Gadolinium-enhanced axial T1-weighted MRI of the brain, showing several enhancing lesions in the right pons/middle cerebellar peduncle (trigeminal nerve entry zone), (C) the left periatral region and subcortical white matter of both cerebral hemispheres; and (B and D) at 3-month follow-up, showing resolution of the previously observed contrast-enhancing supratentorial and infratentorial lesions. (E and G) Sagittal T2 short tau inversion recovery sequence MRI of the cervical and thoracic spine, showing a longitudinally extensive lesion from C5 through T1, lesions involving T10-T11 segments, and conus medullaris; and ( $F$ and H) at 3month follow-up, showing a marked decrease in the size of previously observed cervical, thoracic, and conus medullaris lesions. (I) Teased nerve fiber preparation $(\times 16)$ of the left sural nerve, revealing increased demyelination and remyelination (arrows) and axonal degeneration (asterisks). ()) Semithin epoxyembedded section $(\times 40)$, showing moderately to severely reduced myelinated fiber density and rare degenerating profiles (arrow). (K) CD45 (leukocyte common antigen) preparation (×16), showing reactive individual cells within the endoneurium (arrow) and a single small perivascular epineurial collection (not shown).

improvement with only mild residual neurogenic bladder and erectile dysfunction at 3 months and radiographic improvement of the brain and spinal cord enhancing lesions (figure, $\mathrm{B}$, D, F, H). PNS features also improved with normalization of leg reflexes and complete recovery of the facial palsy and the wrist and foot drop. MOG-IgG1 antibodies were not detected at 9-month follow-up, which might suggest a low relapse risk. ${ }^{6}$

\section{Discussion}

In recent years, some efforts have been made to try to identify antigenic targets and serologic markers in CCPD syndromes. This is a case of confirmed MOG antibody-related demyelinating disease in a patient with CCPD and inflammatory demyelinating polyradiculoneuropathy. Its molecular structure and location on the CNS surface myelin sheath and oligodendrocyte processes predict MOG to be an important target of autoantibodies and cell-mediated immune responses in IDDs. Although the PNS antigen remains elusive in this case, we propose 3 hypotheses to explain the simultaneous CNS and PNS involvement. MOG is found in a secreted isoform, which could be released into the CSF, triggering or "spreading" autoimmunity when drained into the PNS by means of molecular mimicry with peripheral myelin proteins. Although this process would theoretically imply a temporal delay between CNS and PNS symptom onset, a short interval between both cannot be entirely excluded in our patient. In addition, the identification of peripheral MOG expression in rats and primates increases the possibility of an immune response directed to MOG in central and peripheral nerve structures, but this requires further investigations in humans. ${ }^{7}$ Finally, autoimmune attacks could 
potentially target nonshared antigens in both CNS and PNS compartments in individuals with an increased susceptibility to autoimmunity.

PNS involvement should not discourage clinicians from investigating the presence of MOG antibodies in IDDs. We also propose that MOG autoimmunity may play a role in some CCPD cases.

\section{Author contributions}

R. Vazquez Do Campo: manuscript concept and design, drafting of the manuscript, editing of the final text, and review of the literature. A. Stephens and I.V. Marin Collazo: patient care, contributed to manuscript editing, and case discussion. D.I. Rubin: critical review of the manuscript, editing of the final text, and intellectual contribution.

\section{Acknowledgment}

The authors thank Dr. Jennifer M. Martinez-Thompson and Dr. P. James B. Dyck (Department of Neurology, Mayo Clinic Rochester, MN) for providing the sural nerve biopsy images and for interpretation of the histological preparations.

\section{Study funding}

No targeted funding reported.

\section{Disclosure}

R. Vazquez do Campo, A. Stephens, and I.V. Marin Collazo report no disclosures. D.I. Rubin served as an associate editor for Journal of Clinical Neurophysiology, receives royalties from UpToDate, the AAN, and American Association of Neuromuscular and Electrodiagnostic Medicine. Full disclosure form information provided by the authors is available with the full text of this article at Neurology.org/NN.

Received July 13, 2018. Accepted in final form August 2, 2018.

\section{References}

1. Ogata $\mathrm{H}$, Matsuse D, Yamasaki R, et al. A nationwide survey of combined central and peripheral demyelination in Japan. J Neurol Neurosurg Psychiatry 2016;87:29-36.

2. Cortese A, Franciotta D, Alfonsi E, et al. Combined central and peripheral demyelination: clinical features, diagnostic findings, and treatment. J Neurol Sci 2016; 15:182-187.

3. Wang $\mathrm{Y}$, Chen $\mathrm{H}$, Zhuang W, Li H. The clinical features of combined central and peripheral demyelination in Chinese patients. J Neuroimmunol 2018;15:32-36.

4. Tajima Y, Matsumura M, Yaguchi H, Mito Y. Possible combined central and peripheral demyelination presenting as optic neuritis, cervical myelitis, and demyelinating polyneuropathy with marked nerve hypertrophy. Intern Med 2018;57: 867-871.

5. Jarius S, Paul F, Aktas O, et al. MOG encephalomyelitis: international recommendations on diagnosis and antibody testing. J Neuroinflammation 2018;15:134.

6. Lopez-Chiriboga S, Majed M, Fryer J, et al. Association of MOG-IgG serostatus with relapse after acute disseminated encephalomyelitis and proposed diagnostic criteria for MOG-IgG-associated disorders. JAMA Neurol Epub 2018 July 16.

7. Pagany M, Jagodic M, Schubart A, et al. Myelin oligodendrocyte glycoprotein is expressed in the peripheral nervous system of rodents and primates. Neurosci Lett 2003;350:165-168. 


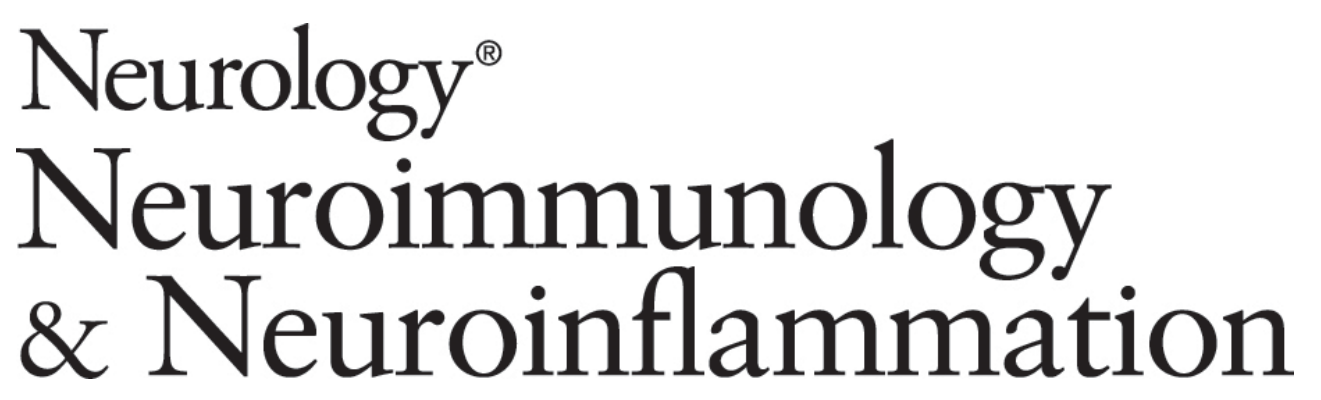

MOG antibodies in combined central and peripheral demyelination syndromes Rocio Vazquez Do Campo, Alana Stephens, I. Vanessa Marin Collazo, et al.

Neurol Neuroimmunol Neuroinflamm 2018;5;

DOI 10.1212/NXI.0000000000000503

This information is current as of September 11, 2018

Neurol Neuroimmunol Neuroinflamm is an official journal of the American Academy of Neurology.

Published since April 2014, it is an open-access, online-only, continuous publication journal. Copyright

Copyright $\odot 2018$ The Author(s). Published by Wolters Kluwer Health, Inc. on behalf of the American

Academy of Neurology.. All rights reserved. Online ISSN: 2332-7812.

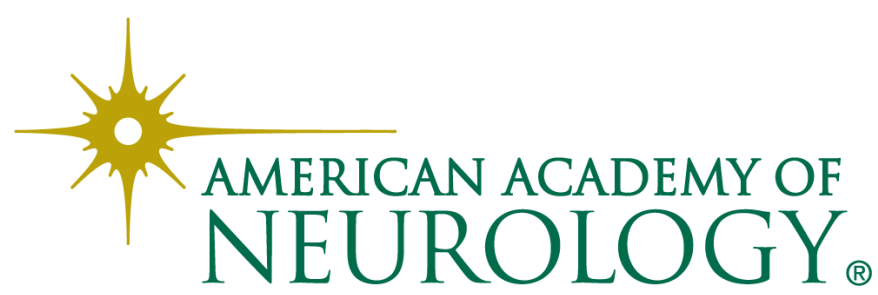




\section{Updated Information \& Services}

References

Citations

Subspecialty Collections

Permissions \& Licensing

Reprints including high resolution figures, can be found at:

http://nn.neurology.org/content/5/6/e503.full.html

This article cites 6 articles, 1 of which you can access for free at: http://nn.neurology.org/content/5/6/e503.full.html\#\#ref-list-1

This article has been cited by 1 HighWire-hosted articles: http://nn.neurology.org/content/5/6/e503.full.html\#\#otherarticles

This article, along with others on similar topics, appears in the following collection(s):

Devic's syndrome

http://nn.neurology.org//cgi/collection/devics_syndrome Guillain-Barre syndrome

http://nn.neurology.org//cgi/collection/guillainbarre_syndrome Multiple sclerosis

http://nn.neurology.org//cgi/collection/multiple_sclerosis

Optic neuritis; see Neuro-ophthalmology/Optic Nerve

http://nn.neurology.org//cgi/collection/optic_neuritis

Transverse myelitis

http://nn.neurology.org//cgi/collection/transverse_myelitis

Information about reproducing this article in parts (figures,tables) or in its entirety can be found online at:

http://nn.neurology.org/misc/about.xhtml\#permissions

Information about ordering reprints can be found online:

http://nn.neurology.org/misc/addir.xhtml\#reprintsus

Neurol Neuroimmunol Neuroinflamm is an official journal of the American Academy of Neurology.

Published since April 2014, it is an open-access, online-only, continuous publication journal. Copyright

Copyright $\odot 2018$ The Author(s). Published by Wolters Kluwer Health, Inc. on behalf of the American

Academy of Neurology.. All rights reserved. Online ISSN: 2332-7812.

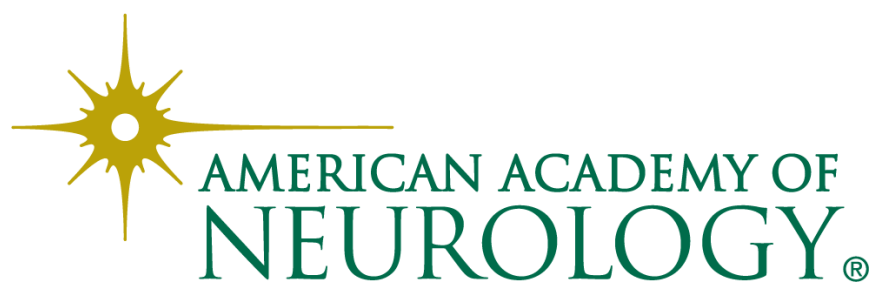

